\title{
Labor mobility and its effects on familiy dynamics
}

\section{Movilidad laboral y sus efectos en la dinámica familiar}

\author{
HERNANDEZ-MAR, Sandra Luz $\dagger^{* *}$, CHAVEZ-DIAZ, Leticia, COBOS-VICENCIO, Rosa María and \\ CALLEJA- MATEOS, Virginia
}

Universidad Veracruzana, Facultad de Trabajo Social. Calle 12 No. 215 Colonia Cazones. Poza Rica, Ver.

ID $1^{\text {st }}$ Autor: Sandra Luz, Hernández-Mar / ORC ID: 0000-0001-7162-9963, Researcher ID Thomson: S-7602-2018, CVU CONACYT ID: 473381

ID $1^{\text {st }}$ Coautor: Leticia, Chávez-Diaz / ORC ID: 0000-0002-3803-0403, Researcher ID Thomson: I-6708-2018, CVU CONACYT ID: 902209

ID $2^{\text {nd }}$ Coautor: Rosa Maria, Cobos-Vicencio/ ORC ID: 0000-0001-8683-2286, Researcher ID Thomson: S-7632-2018, CVU CONACYT ID: 473939

ID $3^{\text {rd }}$ Coautor: Virginia, Calleja-Mateos / ORC ID: 0000-0001-7473-497X, Researcher ID Thomson: S-6789-2018, CVU CONACYT ID: 450327

DOI: $10.35429 / E J R C .2019 .8 .5 .8 .16$

Received March 27, 2019; Accepted June 20, 2019

\section{Abstract}

This research reveals the effects that are presented in families, due to the labor mobility of the oil worker, mainly in its dynamics (communication, cohesion, family adaptability, roles and hierarchy) since it generates a series of problems in the inside of her. In the city of Poza Rica, the main work activity of parents is the oil industry, some of them work in the same city, but others in Ciudad del Carmen, Campeche, on marine platforms, where they have to be absent for 15 days, hence this research seeks to answer: What are the effects of labor mobility on family dynamics? This work is of a qualitative type, with the phenomenological method, it arose from the interest of venturing into reflection, analysis on the subject, which allowed us to dimension the complexity of labor mobility in which various families from urban communities are involved, also because this research means a first approach to the analysis of the effects of labor mobility on the family dynamics of workers in the oil industry, because there is no regional background of research work related to this problem.

Labor Mobility, Family Dynamics, Oil Workers

\section{Resumen}

La presente investigación da a conocer los efectos que se presentan en las familias, por la movilidad laboral del trabajador petrolero, principalmente en su dinámica (comunicación, cohesión, adaptabilidad familiar, roles y jerarquía) ya que genera una serie de problemas en el interior de ella. En la ciudad de Poza Rica, la principal actividad laboral de los padres de familia es la industria petrolera, algunos de ellos laboran en la misma ciudad, pero otros en Ciudad del Carmen, Campeche, en plataformas marinas, donde tienen que ausentarse durante 15 días, de ahí que esta investigación busca dar respuesta a: ¿Cuáles son los efectos de la movilidad laboral en la dinámica familiar? Este trabajo es de tipo cualitativo, el método es el fenomenológico, surgió por el interés de incursionar en la reflexión, análisis sobre el tema, lo que nos permitió dimensionar la complejidad de la movilidad laboral en la que se encuentran involucradas diversas familias de comunidades urbanas, además porque esta investigación significa un primer acercamiento al análisis de los efectos de la movilidad laboral en la dinámica familiar de los trabajadores de la industria petrolera, porque no existen a nivel regional antecedentes de trabajos de investigación relacionados con esta problemática.

Movilidad Laboral, Dinámica familiar, Trabajadores Petroleros

Citation: HERNANDEZ-MAR, Sandra Luz, CHAVEZ-DIAZ, Leticia, COBOS-VICENCIO, Rosa María and CALLEJAMATEOS, Virginia. Labor mobility and its effects on familiy dynamics. ECORFAN Journal-Republic of Cameroon. 2019, 5-8: $8-16$

\footnotetext{
* Correspondence to Author (email: slhm78@ hotmail.com)

$\dagger$ Researcher contributing first Author.
} 


\section{Introduction}

Mobility and migration are as old as humanity itself. Throughout history they have always been an element to guarantee survival or improve the living conditions of societies. In Mexico, mobility occurs with the impact generated by the industrial revolution and the development of cities in the period of stabilizing development (1954-1970), due to the number of labor sources that emerged, causing a pendular migratory movement from the countryside to the city, both in the interurban and peri-urban spaces, and it is here that we can recognize the phenomenon of mobility, originated in principle by displacement to cover labor needs. In the governments of the stabilizing development (Adolfo Ruiz Cortines, Adolfo López Mateos and Gustavo Díaz Ordaz), there were increases in the industry, the sectoral composition of the gross domestic product underwent important changes in favor of the industry to the detriment of the agricultural sector and services.

In the City of Poza Rica, Veracruz, labor mobility is due to the needs of people to seek new job opportunities, such is the case of workers in the oil industry, who have decided to move to another state of the Republic Mexican to have an economic stability and thus be able to meet the basic needs for your family, but although they find better job opportunities, problems can occur within the family. In summary, this article allows us to know the effects that are presented in family dynamics due to the mobility of the head of the family, in relation to the indicators: communication, cohesion, adaptability, roles and authority, based on the model of David H. Olson and Salvador Minuchin.

\section{Problem Statement}

Since the second half of the twentieth century, the sense of mobility is from developing countries or regions to the most advanced. The factors that encourage it are the existence of higher levels of well-being or better social services, together with economic reasons, unemployment, economic crises, which in general cause sometimes forced displacements.
The increase in labor mobility constitutes an increasingly present phenomenon in advanced societies, becoming an increasingly central aspect to interpret social change and the transformations that occur in modern societies (Bauman, 2000; Kaufmann, 2002; Castells , nineteen ninety six). Its expansion can be interpreted both as a cause, as a consequence of the processes of globalization or the development of new communication technologies and their impact, can be analyzed both in the economic and political sphere, and in relation to sociability and above all to the family.

The study of labor mobility has several characteristics and its frequency can give rise to several types, the main being circular mobility, that is, the round trip movement, which would include people who move daily (daily commuters), weekly (weekly) or monthly, irregularly (vari-mobile) or temporarily (Seasonal) (Meil LG, Ayuso SL, 2010).

Returning to the types of labor mobility, in the City of Poza Rica there is a lot of shuttles, who have a second residence, which, in the case of workers in the oil industry, where their residence is within the same workspace, that is to say in the cabins of the marine platform, located in the third level. The type of mobility shuttles gives rise to the so-called weekend marriages or marriages every fifteen days.

The city of Poza Rica, for several decades, has been distinguished as an important industrial enclave in the northern region of the state of Veracruz, on the one hand, it favors its economic activity, but on the other it promotes migration and labor mobility. In 2000, the City began an economic deceleration process by decreasing the local employment index, mainly that of the para-state Petróleos Mexicanos, which caused that the workers of the region decided to emigrate to the states of Campeche and Tabasco to reintegrate into the area called marine platforms.

Life and work on marine platforms is very difficult, since it is a system consisting of a period of fourteen days worked for fourteen days off; Other systems are based on working two weeks and resting for another two weeks and so progressively until reaching a shift of one month, followed by another month of rest and on some occasions, due to the special circumstances of the service provided, they have to work until The work is finished.

HERNANDEZ-MAR, Sandra Luz, CHAVEZ-DIAZ, Leticia, COBOS VICENCIO, Rosa María and CALLEJA- MATEOS, Virginia. Labor mobility and its effects on familiy dynamics. ECORFAN JournalRepublic of Cameroon. 2019 
The isolation in the open sea and the conditions of cold and extreme heat represent precarious working conditions, together with the working hours that are the longest, ranging from 80 to 100 hours per week, but are the most attractive since they are the best remunerated, which is why workers decide to separate from their families and get on the platforms.

The labor mobility of the head of the family is presented as follows: 365 days a year, 14 days are absent each month, giving a total of 168 days a year on the marine platform, with 12 hours per day per workday, approximately 2000 thousand hours a year; The travel time from Poza Rica to Cd. del Carmen and vice versa is 16 hours each, with a total of 32 hours of travel per month and 384 hours per year, leaving only 1816 hours to be with the family.

The workers of the Petróleos Mexicanos company that reside in the city of Poza Rica seek a better paid salary regardless of whether they need to leave their home, however, due to this situation some families present a series of problems that affect each member. Currently there are 1700 PEMEX workers who live in the city of Poza Rica and have labor mobility towards Cd. Del Carmen, section 47 is 1200 workers and section 42 is 500 workers.

Occupational mobility is sometimes a project shared between father, mother and children, perceiving positive changes such as improvements in fraternal relationships, wishes for reunion, greater assessment of the sacrifice of parents, but if not, changes, ruptures or fractures occur in emotional ties, disagreements, quarrels, arguments, bad behavior are experienced, lack of emotional values, translocation of roles (that is, to assume an alien role) that make your life much more difficult.

Many men living in the municipality of Poza Rica, Ver., Found the opportunity to work on the oil platforms in the Campeche probe; So this situation has generated a series of problems in family life, among them, the wife has to assume the role of father and mother, although there are also families where the eldest son is the one who assumes the role of father, in terms of communication in some families becomes scarce, there is a high degree of dependence on a single family member, the children take refuge in the mother, who also exercises authority in the family during the absence of the father.
But when the head of the family returns family after completing their workday, some changes in family dynamics are generated, including the imposition of different rules by the father, causing a lack of control in the children until they reach the loss of authority.

\section{General Objectives}

Analyze the effects of labor mobility on the family dynamics of workers in the oil industry to improve family relationships.

\section{Specific objectives}

Identify the factors that describe family dynamics and how they change with work mobility.

Describe how the absence of the head of the family leads to changes in the exercise of authority.

\section{Methodology}

The approach of the present investigation is qualitative because it seeks the understanding of human behavior and the reasons that govern it, which in this case we talk about the labor mobility of the head of the family and his motivations to be absent in the search to improve the quality of life of his family, exploring social relationships and describing reality as experienced by social actors, understanding the experience of each family member. This research is based on phenomenology because the meanings that each family member assigns to the experiences on how family dynamics are modified when the head of the family decides to have work mobility are described.

The research was conducted in the municipality of Poza Rica, Veracruz. The subjects of study will be four of them whose head of family has labor mobility, whose characteristics are:

Families with work mobility

- $\quad$ Work in PEMEX on a marine platform.

- $\quad$ Families with teenage or young children.

- Workers who work 14 x 14 days.

- $\quad$ Heads of family with working age of 5 to 20 years. 
Research Techniques and Instruments

$\begin{array}{ll}- & \text { Observation } \\ - & \text { Interview } \\ - & \text { Life story } \\ - & \text { Familiogram }\end{array}$

\section{Theoretical framework}

\section{Labor Mobility}

Long, J. (2011) mentions that labor mobility is the geographical and occupational movement of workers. Worker mobility occurs more easily when there are no impediments to this happening. Mobility impediments are easily divided into two distinct classes, one being personal and the other systematic. Personal impairments include physical location and mental and physical abilities. Systematic impediments include educational opportunities and also laws and political restrictions, including barriers and conflicts that arise from historical issues. It is worth mentioning that the definition of Long, J. will be the one that will be used for this work.

\section{Family transformations due to the mobility effect}

\section{Family reorganization}

All the movements carried out by household members (mainly men who work on PEMEX platforms) involve the participation of all members of the family as a whole. Each movement of a family member (father, brother, husband, son, etc.), involves the rearrangement of the functions and roles that each member has in the family structure.

For example, women remain in charge of the care and attention of the home, the children get to readjust their school and productive activities, because now the mother has many more activities that she sometimes fails to accomplish due to lack of time. With the labor mobility of the heads of family, the domestic group reorganizes its activities to meet their needs, in addition the roles of each of the individuals are altered and intensified, particularly that of the woman, who assumes the main authority of The family during the father's workday is now the one who distributes the activities and tasks.

\section{New structures in the family}

The family is the fundamental social organization par excellence, however, its basic characteristic is the ease of adaptation to any situation, no matter how difficult it is, this function allows you to endure and manage the different contexts and realities in a space of time or in different places (Gutiérrez, 2005). With globalization many transformations have been perceived in all societies and cultures, the family nucleus has not been the exception since, being nuclear families, from migration they become single parents (mother in charge of children, father to in charge of children) and extended (children in charge of grandparents, children in charge of older siblings, children in charge of uncles).

In addition to the aforementioned classification, it is also important to analyze other typologies that have been emerging in families with labor mobility, such as: accordion (Casas F., 2010), uncontrolled (Minuchin, S., 1987) and LAT families (Living Apart Together) (Ariza and Oliveira, 1999); Regardless of what the family means for us, for society and for the time we live, several types of family are distinguished.

\section{Transnational Families}

Transnational families can be defined, according to Bryceson and Vuorela (2002), as families whose members live part or most of the time apart, but who stand together and create something that can be considered as a feeling of collective well-being and unity - it is that is, of familyhood, as the authors call it, "and even exceeds national boundaries. Other authors prefer the use of the term" home "to define such training as a group of people who, despite having been separated by migration, they are linked by direct economic ties, such as those associated with the flow of remittances (Zlotnik, 2000).

\section{Family dynamics}

For Olson, family dynamics is the system of exchange in family interactions, specifically the emotional ties that family members have with each other, the way they dialogue with each other (communication), the degree of individual autonomy that a person experiences in the family (cohesion), the role that each one performs within the family (roles). 
As well as the ability of the family system to combine its power structure (authority), its roles, its relationship rules in response to stress, situational and developmental (adaptability) (Olson, Russell and Sprenkle, 1979). Family dynamics can be interpreted as meetings mediated by a series of norms, rules, limits, hierarchies and roles, which regulate coexistence and allow the functioning of family life to develop harmoniously.

According to Minuchin (1977), family dynamics include aspects raised within the family, where each and every member is linked to others by kinship ties, relationships of affection, communication, boundaries, hierarchies or roles. of decisions, conflict resolution and the functions assigned to its members. The family dynamic is composed of a set of positive and negative forces that affect the behavior of each member of the system (Cabrera, Rodríguez, González, Ocampo and Amaya, 2006).

The dynamics can be commonly translated into functional or dysfunctional. Functionality means those systems that encourage socialization by giving its members all the support and satisfactions that are necessary for their personal and social development (Minuchin, 1977). While due to dysfunctional it refers to a type of conflictive family or in which conflicts occur, which make it not work in today's society, the interaction that occurs in dysfunctional families is uncomfortable and is lacking among the members (Martínez, N .M, 2006). It is important to mention that functional families or not, go through periods of crisis, enjoy competent areas and have maladaptive functions over a period of time.

Family dynamics is defined under the concepts of family structure and composition, family types, family relationships, family functions, communication, rules, norms and values, so there are minimum conditions for achieving a healthy family dynamic such as: clear rules of coexistence within the family, that the family has adequate mechanisms to deal with conflicts, that there is a clear and direct dialogue, an emotional link with independence and spaces for each member, in addition to an equitable distribution of tasks of home.
From the beginning of David H. Olson's studies (1979), at the end of the seventies he understood that the three dimensions: cohesion, communication and family adaptability, are the result of an inductive conceptual grouping, as well as being key in the treatment of the couple and families. The three dimensions according to Olson (1979), can be organized in a circumflex model that graphically facilitates the identification of 16 types of family, in addition this model tries to assemble theory, research and family therapy.

In turn, Minuchin (1977) establishes that in the family clear roles must be established for the fulfillment of the tasks and hierarchy to regulate the behavior of the members, especially when the figure of the head of the family is missing.

\section{Characteristics of family dynamics}

\section{Cohesion}

Family cohesion is defined by Olson (1979) according to two components: "the emotional bond that they have among the members of a family, and the level of individual autonomy that a person experiences within the scope of their own family." The indicators to evaluate in this dimension are: emotional bonding, independence, limits, coalitions, time, space, friends, decision making, interests and recreation.

Cohesion is defined as "the degree to which family members are interested in it, commit to it and help each other" (Moos 1976, cited by Simon 1988). It refers to the degree to which family members have a sense of union and belonging. This degree of family union is reflected in the support and cooperation between family members both for daily activities and for solving problems, as well as sharing interests and free time.

Family cohesion refers to the strength of the bonds that unite family members and translate into behaviors such as having common friends and interests, establishing coalitions, sharing time and space. The degree of cohesion is related to the differentiation of each of its members. Extreme differentiation threatens to disintegrate the family and excessive cohesion threatens to destroy the space for personal growth. 


\section{Communication}

Communication is a crucial point because family relationships are crossed by the exchange of thoughts, emotions and feelings between people linked to the family group and that are externalized through verbal and nonverbal action and / or language.

According to Olson et al. (1979), positive communication (open, empathetic, supportive comments, attentive listening) allow marriages and families to share (communicate) with each other the changes in their needs and preferences, regarding their ways of functioning as spouses and family. On the contrary, negative communication (double messages, unclear messages, excessive and destructive criticisms, etc.), minimizes the ability of the couple and the family to share and share their feelings and needs, therefore, limit the possible displacements in the dimensions of cohesion and adaptability, that is, the separation of physical and emotional space is maximized, therefore, they are not able to negotiate and face problems together.

\section{Family Adaptability}

Another of the main contributions of the general theory of systems to the family sphere is, in the opinion of Olson et al (1979), to have demonstrated the relevance of adaptability.

Adaptability, also known as flexibility, focuses on the family's ability to change their power structures, the dynamics between roles and norms in response to the demands placed on them, including family leadership, control, discipline, negotiation style, role relationships and relationship rules.

The adaptability of a family depends on its ability to create a flexible balance between an excessively changing situation (which results in chaotic systems) and an excessively stable situation (which results in rigid systems). The indicators to evaluate are: Power (assertiveness, control and discipline), negotiation styles and possible exchange and modification of roles and rules of relations. Adaptability is one of those family resources that benefits all family members, especially when long-term demands are present and when daily life cannot be predicted. Being able to change speed, hopes and alter the roles and rules contributes to obtaining better results.
Sometimes adaptability has been understood as a "yield" always to avoid conflicts, being flexible does not mean getting carried away and being condescending to everything and everyone. Learning to listen and observe carefully everything that happens around us, is the starting point to take the best of every circumstance and put aside everything that objectively is not convenient.

\section{Family roles}

Family roles is another indicator that is part of the characteristics of family dynamics being the theoretical reference to explain this variable Minuchin (1977).

The structural aspects of the family correspond to the variables that relate to the type of family, number of members, existing subsystems, that is, those that arise within a family such as dyads, (husband-wife, motherchild or brother-sister). The roles that each one fulfills, the internal and external limits, the alignments and the management of power, these guidelines establish how, when and with whom of the family members it relates, regulating in turn the behavior between them.

Minuchin (1977) expresses that the structure of the family system is relatively fixed and stable to help the family in the fulfillment of tasks, protect it from the external environment and give them a sense of belonging to its members. But in turn, it must be able to adapt to the stages of evolutionary development and to the different needs of life thus facilitating family development and individuation processes.

This author states that roles are tasks that each one is expected to fulfill within the family organization and that are partly defined by the culture and partly by the family itself. The assignment of family roles is a process that consists in the unconscious assignment of complementary roles to family members, the function of the roles is to maintain the stability of the family system. The roles are the totality of expectations and norms that the members of the family have regarding the position that each of the individuals should keep, that is, a role is equivalent to the expectations of behavior that are directed towards an individual in a social situation or context, in the familiar are the functions of each individual exercised within the family. 


\section{Hierarchy}

For Minuchin (1989), the hierarchy is the degree of authority or influence that a member has on the behavior of others, must be in the parents or guardians, since this provides security to the children. It also states that the hierarchy reflects the way in which power and authority are distributed within the family. A functional system is organized hierarchically; The management and distribution of power in the family explains its hierarchical organization.

Family authority refers to the obligation that parents have to exercise authority in their family to promote moral growth, capacity development and the autonomy of their children. As well as maintaining family unity and contributing to the improvement of society. This same concept explains why the authority has a service purpose (Flor, M., 2010).

For family authority to be exercised properly it must have the purpose of serving. That is, seeking good and improving all its members. To put it into practice, parents must first agree on the educational objectives that will guide them in this task. This way they will be able to know in what they will be demanding, in what circumstances they should proceed firmly, in which they can be flexible, or when the intervention of the eldest children or some other person will be necessary.

\section{Results}

For the analysis of the results, the family dynamics indicators proposed by Olson were considered, which are: communication, cohesion and family adaptability, and those indicated by Minuchin: roles and hierarchy; Given the amount of information obtained and to facilitate its understanding, a table containing the results obtained was prepared.

Next, the following table is presented where the changes in family dynamics in families with mobility are emphasized.

\begin{tabular}{|c|c|}
\hline $\begin{array}{l}\text { Family } \\
\text { dynamics } \\
\text { indicators }\end{array}$ & $\begin{array}{c}\text { Family } \\
\text { with mobility }\end{array}$ \\
\hline Cohesion & $\begin{array}{l}\text { Fam. 1: Agglutinated } \\
\text { Fam. 2: Unlinked } \\
\text { Fam. 3: Separated } \\
\text { Fam. 4: Agglutinated }\end{array}$ \\
\hline Communication & $\begin{array}{l}\text { Fam. 1: Negative } \\
\text { Fam. 2: Positive } \\
\text { Fam. 3: Negative } \\
\text { Fam. 4: Negative }\end{array}$ \\
\hline $\begin{array}{l}\text { Family } \\
\text { Adaptability }\end{array}$ & $\begin{array}{l}\text { Fam. 1: Chaotic } \\
\text { Fam. 2: Chaotic } \\
\text { Fam. 3: Structured } \\
\text { Fam. 4: Chaotic }\end{array}$ \\
\hline Roles & $\begin{array}{l}\text { Fam. 1: } \\
\text { Role / Mother } \\
\text { Fam. 2: } \\
\text { Role / eldest daughter } \\
\text { Fam. 3: } \\
\text { Role / eldest son-mother } \\
\text { Fam. 4: } \\
\text { Role / Mother } \\
\end{array}$ \\
\hline Hierarchy & $\begin{array}{l}\text { Fam. 1: Mother } \\
\text { Fam. 2: Older Daughter } \\
\text { Fam. 3: Mother } \\
\text { Fam. 4: Mother }\end{array}$ \\
\hline
\end{tabular}

Table 1 Effects of labor mobility on family dynamics Source. Own Elaboration

It is observed in the previous table that labor mobility does have negative effects on each of the indicators of family dynamics, and that, therefore, family relationships deteriorate when changes in the exercise of authority and roles are generated. of the members.

\section{Conclusions}

This research was analyzed from a family perspective, since it is relevant to investigate how over the years man has always moved from one place to another, whether in search of new labor markets, better living conditions or Good for personal and family development.

The research is intended to raise awareness of the problems faced by families when the head of the family presents labor mobility, in addition to knowing what their repercussions are in their family dynamics, therefore, what this research foresees to change is the vision that You have in relation to this problem, since some situations that change your family dynamics can occur. 
Labor mobility plays a key role in advanced societies because of its ability to alter the rhythms of daily life. Approaches to their study have been made in our country from different perspectives: the economic, demographic and human geography, however, it is necessary to develop a new perspective; That is why this research is done from a family perspective.

Families with a worker in the oil industry face different problems in their family dynamics, especially when the head of the family leaves for extended periods of time to work in another state. The problems experienced by these families are disagreements, fractures in emotional ties, redistribution and resignification of the roles that physical absence implies, negative communication between members, lack of authority, lack of cohesion, to name a few problems.

The factors that describe family dynamics are cohesion, communication, family adaptability, roles and hierarchy which were modified as follows: The effects of labor mobility on the family dynamics of oil industry workers are presented with greater incidence in three of the four families, being the main changes from their family structure since being nuclear-type families, with the passage of time and by the absence of the father they became single-parent families due to the separation or divorce of the parents and a family is still of the extended type.

Regarding the communication, in two families there is negative communication, of a damaged type between the wife and the children because there are few clear messages, criticisms and reproaches for the absence of the father, in a family the communication is positive between the head of the family with the eldest daughter, but with the youngest daughter is negative and in another family is negative between the head of the family and the eldest son.

The communication is positive with the mother in all the families, because they are with those who spend the most time and with whom they live more in the special moments, although she is the one who imposes the rules to them.
In family cohesion, those who have a head of family with labor mobility are characterized by a high degree of dependence between the mother and the children, among the siblings, who come to establish dyads and present themselves after the separation of the parents, limiting the personal autonomy.

Adaptability in families with a head with labor mobility is identified by the absence of leadership and lack of responsibility in the father, especially from the separation or divorce of the marriage. As there are changes of roles among family members, there is a greater degree of discipline and rules on the part of the mother and in a family is the eldest daughter, who, in the absence of the father, mentions that they acquire greater commitment for taking care of the family, more than when they were working.

In the families with labor mobility it was observed that the main figure of the household begins as the mother due to the absence of the head of the family, however, with the passage of time in two families this role remains indefinitely to the mother, because due to the separation of marriage, now she is the one who assumes the two figures with the greatest responsibility and in a family the role of head chief whether or not the father assumes the eldest daughter, it is worth mentioning that one of the mothers allows on different occasions that the eldest son assumes The role of the parent. The authority in the families with member with labor mobility is exercised by the mother in three families and in one by the eldest daughter, they are those who distribute the activities and tasks to the members, in addition to solving the problems and needs presented in the family.

The contribution of this research is that there are no studies at the state, regional and regional level on the relationship between labor mobility and family dynamics, they are only found in the international arena, so this research is a pioneer in presenting current information on the problems they face families from the labor mobility of the head of the family. The main beneficiaries in this research will be readers interested in family issues and labor mobility, since as mentioned there are no related documents in this area, it is also important that representatives of the Mexican oil company know the situations they live their workers and their families, to later be able to generate intervention proposals for their benefit. 


\section{References}

Agudelo, B. M. (2005). Descripción de la dinámica interna de las familias Monoparentales, simultáneas, extendidas y compuestas del municipio de Medellín, vinculadas al proyecto de prevención temprana de la agresión. Revista Latinoamericana de Ciencias Sociales, Niñez y Juventud.

Baltazar, G. (2003) Migración paterna, ¿cambio de roles en la familia? Estudios sobre las familias Vol. 2 DIF Jalisco.

Bauman, Z. (2000) Liquid Modernity. Cambridge: Polity Press.

Bryceson, D., y U. Vuorela (2002), "Transnational families in the Twenty-first Century", The Transnational Family, D. Bryceson y U. Vuorela (eds.), Oxford, Berg

Cabrera, C. E., Rodríguez, I., González, G., Ocampo, P. Y Amaya, C. (2006), Aptitud clínica de los médicos familiares en la identificación de la disfunción familiar en unidades de medicina familiar de Guadalajara, México. Distrito Federal: Revista salud mental. Vol. 29, núm. 004.

Casas F. G. (2010) Las configuraciones familiares. Universidad de Costa Rica Escuela de Trabajo Social y Cátedra de Psiquiatría y Psicología Clínica.

Castells, M. (1996) La era de la información: economía sociedad y cultura. Madrid: Editorial Alianza.

Cardona, L. F., Melendo, G. T. (2012) presentan una clasificación de diversas formas de relaciones familiares.

Gutiérrez, Cuauhtémoc A (2005). Introducción a las Ciencias Sociales, Ed. Limusa, México.

Herrera y Martínez. (2002). La emigración a Estados Unidos desde esta zona del Ecuador y la conformación de redes transnacionales. Estudiada por Kyle, 2000 y Jokisch (2004), inédito, entre otros.

Long, J. (2011). Labour Mobility. Oxford: Encyclopedia of Economic History.
Martínez, M. (2006), La investigación cualitativa (síntesis conceptual) Revista IIPSI Facultad de Psicología. UNMSM ISSN: 1560909X, Vol. 9 No. 1.

Meil, L. G., Ayuso S. L. (2010), Movilidad laboral geográfica y vida familiar, España: Ed. Departamento de Sociología, Facultad de CC. Económicas, Universidad Autónoma de Madrid.

Minuchin, S. (1977), Familias y terapia familiar. Barcelona: Editorial Crónica.

Minuchin, S. (1989). Familias y terapia familiar. México: Gedisa.

Nicholson, (1997), The Second Wave: A Reader in Feminist Theory. N.Y.: Routledge,

Olson, H. D. (1979), Módelo circumflejo del sistema marital y familiar. Barcelona, España.

Olson, D., Russell, C., \& Sprenkle, D. (1979), Circumplex model of marital and family systems: VI. Theoretical update. Family Process, 22, New York: Oxford University Press.

Soriano, M. S. (2005), Nuevas formas de organización familiar: matrimonios a distancia, Granada: Universidad de Granada. (Tesis doctoral).

Kaufmann, V. (2002) Re-thinking Mobility. Contemporary Sociology. Aldershot, Burlington: Ashgate.

Zapata, G. (2019). Epicentros de emigración: un análisis comparativo de la evolución de sus dinámicas socioeconómicas y demográficas en Colombia y el Brasil.

Zlotnik, H. (2000), "Migration and the family: the female perspective", Gender and Migration, K. Willis y B. Yeoh (eds.), Edward Elgar. 